\title{
Ecological implications of changes in cell size and photosynthetic capacity of marine Prymnesio- phyceae induced by ultraviolet-B radiation
}

\author{
Behzad Mostajir ${ }^{1, *}$, Tèlesphore Sime-Ngando ${ }^{2}$, Serge Demers ${ }^{1}$, Claude Belzile ${ }^{1}$, \\ Suzanne Roy ${ }^{1}$, Michel Gosselin ${ }^{1}$, Jean-Pierre Chanut ${ }^{1}$, Stephen de Mora ${ }^{1}$, \\ Juliette Fauchot ${ }^{1}$, Francesca Vidussi ${ }^{1}$, Maurice Levasseur ${ }^{3}$ \\ ${ }^{1}$ Groupe de Recherche en Environnement Côtier, Institut des Sciences de la Mer de Rimouski, Université du Québec \\ à Rimouski, 310 Allée des Ursulines, Rimouski, Québec G5L 3A1, Canada \\ ${ }^{2}$ Laboratoire de Biologie Comparée des Protistes, UPRES-A CNRS 6023, Université Blaise Pascal (Clermont-Ferrand II), \\ 63177 Aubière Cedex, France \\ ${ }^{3}$ Institut Maurice-Lamontagne, Ministère des Pêches et des Océans, CP 1000, Mont-Joli, Québec G5H 3Z4, Canada
}

\begin{abstract}
A natural planktonic assemblage of organisms $(<240 \mu \mathrm{m})$ was studied in mesocosm experiments for $7 \mathrm{~d}$ under varying conditions of ultraviolet-B radiation (UVB: 280 to $320 \mathrm{~nm}$ ): UVB excluded, natural radiation and UVB enhanced at 2 different levels. Specifically, the changes in Prymnesiophyceae abundance and light scatter properties attributed to cell size (CS) were investigated by flow cytometry during the first $72 \mathrm{~h}$ with $4 \mathrm{~h}$ temporal resolution and were thereafter examined during the 4 following days with twice daily sampling. In addition, the specific rate of photosynthesis ( $P^{\text {cell }}$ ) of phytoplankton $<5 \mu \mathrm{m}$, ciliate abundance (predator 15 to $35 \mu \mathrm{m}$ ) and dynamics of nutrients were monitored. Prymnesiophyceae ranged in size between 2.7 and $4 \mu \mathrm{m}$ and dominated the phytoplanktonic community $<5 \mu \mathrm{m}$ (more than $94 \%$ ). Prymnesiophyceae exhibited marked diel variability with synchronized cell division: CS increased during the day and diminished at nighttime, indicating cell division. Shortterm UVB exposures during the first $3 \mathrm{~d}$ of the experiment did not affect CS, prosably due to vertical water mixing in the mesocosms moderating harmful UVB exposure. In contrast, long-term UVB treatments ( 3 to $7 \mathrm{~d}$ ) induced progressive CS increases in Prymnesiophyceae as a function of increasing UVB doses. The successive inhibition of $\mathrm{P}^{\text {cell }}$ of phytoplankton $<5 \mu \mathrm{m}$ was also observed as a function of increasing UVB doses. The results suggest that enhanced UVB provokes the retardation of cell division and inhibition of $\mathrm{P}^{\text {cell }}$ which causes Prymnesiophyceae CS enlargement. CS enlargement and probably a change in the food quality of Prymnesiophyceae could result in food limitation for the ciliate population, although ciliates seem to be directly affected by UVB enhancement. This study highlights the ecological implications of CS changes and photosynthetic capacity of phytoplankton, with respect to predator-prey interactions in response to UVB enhancement.
\end{abstract}

KEY WORDS: Ultraviolet-B Prymnesiophyceae - Cell size Photosynthetic capacity - Trophic interactions

\section{INTRODUCTION}

The discovery of large-scale ozone depletion in Antarctica during springtime has prompted investigations on the effects of the resulting enhanced ultraviolet-B (UVB) radiation ( 280 to $320 \mathrm{~nm}$ ) on natural water communities. Notable ozone depletion has now been

•E-mail: behzad_mostajir@uqar.uquebec.ca observed in both polar regions, as ozone loss rates in the Arctic region in recent years have reached values comparable to those recorded over the Antarctic (Rex et al. 1997 and references therein). Moreover, Arctic ozone values in 1996 were briefly about $30 \%$ below normal, while during the spring of 1997 they were as much as $45 \%$ below normal over the high Arctic and about $7 \%$ below normal over the mid-latitude regions of Canada (Tarasick \& Fioletov 1997). 
Numerous investigations on the influence of enhanced UVB have focused on phytoplankton because of their importance as primary producers. Phytoplankton are sensitive to UVB, which reduces the rate of primary production (Smith et al. 1980, Cullen \& Lesser 1991, Smith et al. 1992, Vincent \& Roy 1993), inhibits growth, photosynthesis and cell division (Calkins \& Thordardottier 1980, Jokiel \& York 1984, Karentz et al. 1991), and induces changes in the algal species composition (Neale et al. 1994, Davidson et al. 1996). In addition, with respect to the physiological response of phytoplankton to enhanced UVB, several scientists have shown that UVB can lead to an increase in phytoplanktonic cell volume. For example, in the presence of ambient UVB over a $20 \mathrm{~d}$ period, the cell volumes of the estuarine diatom Phaeodactylum tricornutum were found to be greater than in the absence of UVB radiation (Behrenfeld et al. 1992). Van Donk \& Hessen (1995) found that the green alga Selenastrum capricornutum under UVB stress can double its cell volume within $48 \mathrm{~h}$. Similar increases in both cell volume and chloroplast content have been reported for a marine diatom community (Buma et al. 1996).

Although the finding that the size of phytoplankton cells changes under enhanced UVB is not novel, its ecological implications have rarely been elucidated. This is particualrly true for predator-prey interactions. The microbial food web is governed by a complex web of nutrient competition and trophic interactions between heterotrophic bacteria, small eukaryotic algae, cyanobacteria and Protozoa. The physiological changes of each component under environmental stress, such as enhanced UVB, certainly influence the other compartments. The nature of pelagic ecosystem responses to increased UVB radiation, via its effect on trophic interactions, is to date the most elusive ecological question related to UVB impact studies. For instance, recent investigations have either confirmed or rejected the influence of UVB radiation on the relationship between predator and prey (for details see Mostajir et al. 1999 and references therein).

To elucidate the effect of UVB on the trophic interactions at the base of a temperate microbial food web, a mesocosm approach was adopted. Surface water from the lower St. Lawrence Estuary was subjected to varying regimes of UVB radiation with continuous vertical mixing of the water column. This paper describes both short-term (diel cycles) and long-term (1 wk) UVBinduced changes in cell size (CS) and the specific rate of photosynthesis ( $\mathrm{P}^{\mathrm{cell}}$ ) of phytoplankton $<5 \mu \mathrm{m}$, largely dominated by Prymnesiophyceae, which represented more than $94 \%$ of the cell numbers of the phytoplanktonic community $<5 \mu \mathrm{m}$ during this experiment. In addition, the dynamics of the presumed predators, i.e. ciliate Protozoa (Mostajir et al. 1999), were described in order to elucidate the role of predator-prey interaction in response to Prymnesiophyceae reactions to UVB enhancement.

\section{MATERIALS AND METHODS}

Experimental setup. The mesocosm experiments were performed on the south shore of the lower St. Lawrence Estuary (Québec, Canada, $48.6^{\circ} \mathrm{N}, 68.2^{\circ} \mathrm{W}$ ) from July 17 to 23,1996 . A time-series experiment was carried out for 7 d using 8 land-based mesocosms (depth $2.25 \mathrm{~m}$, Fig. 1) each containing $1500 \mathrm{l}$ of St. Lawrence Estuary surface water, previously passed through a $240 \mu \mathrm{m}$ Nitex screen. The experimental setup, including natural and experimental light regimes, has been described in detail elsewhere (Belzile et al. 1998). Briefly, 4 tanks each containing pairs of mesocosms were submitted to 4 UVB treatments: (1) natural UVB (NUVB) as control, (2) low UVB (LUVB) enhancement, (3) High UVB (HUVB) enhancement and (4) without UVB (WUVB). The UVB intensities were increased using 2 (LUVB) and 3 (HUVB) lamps (model $\mathrm{XX15B}$, Spectronics Corporation) with an emission peak at $312 \mathrm{~nm}$, which were turned on from 09:00 to 17:30 h. The shorter wavelengths, not encountered in nature but emitted by the lamps, were eliminated by covering the lamps with aged (for $1 \mathrm{~h}$ at $1 \mathrm{~cm}$ distance from the lamps) $0.13 \mathrm{~mm}$ cellulose acetate sheets that were changed daily. In the WUVB treatment, natural UVB radiation was removed by a $0.13 \mathrm{~mm}$ Mylar ${ }^{\circledR} \mathrm{D}$ sheet. To ensure the same shading conditions in each treatment, 3 dummies (wooden lamp replicate) were installed over the NUVB mesocosms and 1 dummy was added to the lamps over the LUVB mesocosms. No dummies were installed over the WUVB mesocosms because the Mylar ${ }^{\circledR}$ sheet already somewhat reduced UVA (320 to $400 \mathrm{~nm}$ ) and PAR (photosynthetically available radiation, 400 to $700 \mathrm{~nm}$ ). Incident irradiance was recorded every $10 \mathrm{~min}$ during the experiment using an IL 1700 radiometer with SUD033/PAR/ QNDS1/W (PAR), SUD033/UV-A/W (UVA), SUD240/ SPS300/T/W (UVB) sensors which provided a cosinecorrected irradiance (International Light Inc.). UV irradiance through the water column was measured using a PUV 500 profiling radiometer (Biospherical Instruments) and an Optronic Laboratories OL 752 spectroradiometer. The PUV 500 radiometer provided a measure of cosine-corrected downwelling irradiance at $305,320,340,380 \mathrm{~nm}$ and PAR. A correction factor of 2.6 was applied to the absolute irradiances at $305 \mathrm{~nm}$ measured with the PUV 500 to compensate for the underestimation caused by the lamp calibration method (Kirk et al. 1994). 
A

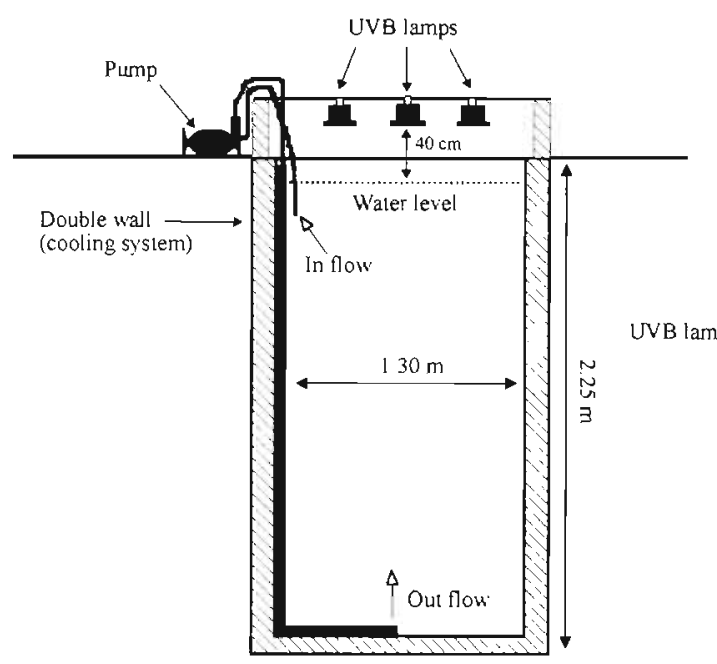

B

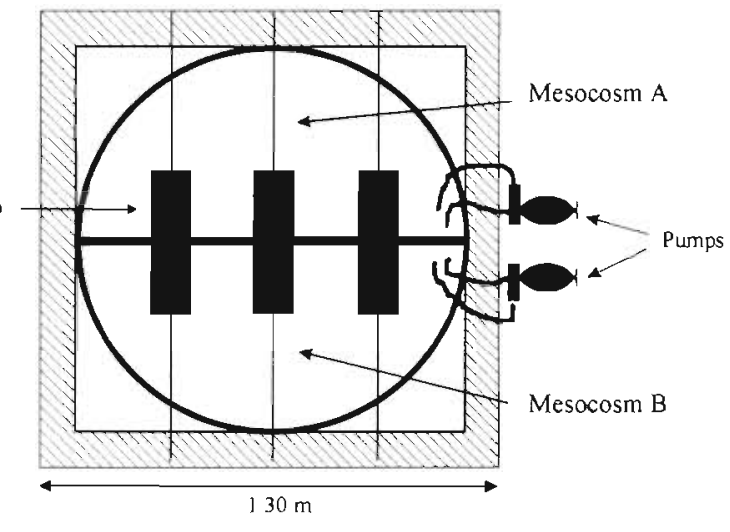

Fig. 1. Schematic representation of the (A) side view and (B) top view of the mesocosm system (modified from Belzile et al. 1998)

The irradiance attenuation coefficient $\left(K_{d}\right)$ in the mesocosms was calculated based on measurements using the PUV 500 radiometer. Temperature regulation was achieved by circulating local estuarine water around the mesocosms. The water temperature was measured every hour between the 2 mesocosms in each tank with thermocouples (type ' $\mathrm{J}$ ') connected to a datalogger (21X, Campbell Scientific). In each mesocosm, vertical profiles were obtained using the temperature sensor of the PUV 500 radiometer. To ensure a homogeneous water mass, the water in each mesocosm was continuously mixed using a small pump (Little Giant ${ }^{\circledR}$, model 2-MD-HC), achieving a turnover time of $1 \mathrm{~h}$.

Nutrients. Samples for nutrient measurements were collected from each mesocosm at 09:00 and 13:00 h daily. Aliquots of 40 to $50 \mathrm{ml}$ of sample were filtered $(<10 \mathrm{~cm} \mathrm{Hg}$ ) through Whatman GF/F filters. Inorganic nutrients were analyzed in the filtrates. The concentration of ammonium was determined immediately using the method of Solorzano (1969) as described by Parsons et al. (1984). The remainder of the filtrate was frozen at $-20^{\circ} \mathrm{C}$ for subsequent analysis of nitrate plus nitrite, nitrite, and silicate using a Perstorp FS III Autoanalyzer (Parsons et al. 1984).

Flow cytometric analysis. Samples for flow cytometric analysis were taken every $4 \mathrm{~h}$ during the first $3 \mathrm{~d}$ of the experiment $101: 00,05: 00,09: 00,13: 00,17: 00$ and 21:00 h). During the 4 following days, samples were collected twice daily $(09: 00$ and 17:00 h). Several phytoplankton populations including $<4,4$ to 5 and 5 to $20 \mu \mathrm{m}$ were analyzed immediately after sampling using a FACSORT Analyzer flow cytometer (BectonDickinson) fitted with a $488 \mathrm{~nm}$ laser. However, in this paper, only the abundance and forward light scatter (FSC) of the $<4 \mu \mathrm{m}$ algal cell community are reported. The FSC in the present investigation is attributed to mean cell size (CS); however, there are other factors which can influence FSC such as refractive index and cell shape. For example, a laboratory study on the diatom Thalassiosira pseudonana over the diel cycle has shown that the refractive index can have a greater affect on cell scatter than CS (Stramski \& Reynolds 1993). Another study has shown that variations in CS are more important to changes in FSC than are changes in refractive index for a chlorophyte (DuRand \& Olson 1998). Prior to analysis, phytoplankton were kept in the dark at $4^{\circ} \mathrm{C}$ for a maximum of $2 \mathrm{~h}$ and samples from different treatments were analyzed in random order. The flow rate was set to $12 \mu \mathrm{min}^{-1}$ and the acquisition time was at least $5 \mathrm{~min}$. Two separate samples from each mesocosm were analyzed after the addition of $10 \mu \mathrm{m}$ beads (Immunocheck, Coulter) as an internal standard. The data were logged using Cell Quest software and analyzed with Attractors software, both from Becton-Dickinson. To verify the stability of the cytometer during the experiment, CS signals were verified with those of calibration beads using the fixed attractors.

Primary production measurements. Measurements of in situ carbon fixation by phytoplankton in each mesocosm were made daily. For each mesocosm, two $100 \mathrm{ml}$ samples were taken from $15 \mathrm{~cm}$ below the water surface and then dispensed in Whirl-Pak bags and were inoculated with $148 \mathrm{kBq}(4 \mu \mathrm{Ci})$ of $\mathrm{NaH}^{14} \mathrm{CO}_{3}$. The total added radioactivity was determined on stored aliquots of inoculated samples. The samples were incubated from $10: 00$ to $14: 00 \mathrm{~h}$, floating 
on the water surface, and were exposed to abovewater radiation intensities. At the end of the incubation, the samples were fractionated on Whatman GF/F filters (total production) and $5 \mu \mathrm{m}$ polycarbonate filters (Poretics) (production of large algae $>5 \mu \mathrm{m}$ ). The filters were subsequently put into scintillation vials, acidified with $1 \mathrm{ml}$ of $0.5 \mathrm{~N} \mathrm{HCl}$ and then shaken in a hood to expel inorganic ${ }^{14} \mathrm{C}$ (Lean \& Burnison 1979). The Ecolume scintillation cocktail was added to the samples, which were counted using a Beckman LS5801 scintillation counter. The counts were dark corrected. Carbon fixation rates were computed according to Parsons et al. (1984). The primary production of phytoplankton $<5 \mu \mathrm{m}$ was calculated by subtracting the primary production of algae $>5 \mu \mathrm{m}$ from the total $(G F / F)$ primary production. The phytoplankton $<5 \mu \mathrm{m}$ size fraction was largely dominated by Prymnesiophyceae (see below). The specific rate of photosynthesis ( $\mathrm{P}^{\text {cell }}$ ) for phytoplankton $<5 \mu \mathrm{m}$ was calculated by dividing the primary production of phytoplankton $<5 \mu \mathrm{m}$ by their abundance estimated by flow cytometry,

Microscopic phytoplankton identification. A combination of DAPI-fluorescence, Nomarski differential interference contrast optics, and Utermöhl inverted microscopy was used for the identification of the acid Lugol fixed $<5 \mu \mathrm{m}$ phytoplankton community. This combined optical system has been shown to encompass the advantages of 3 methods: Utermöhl sedimentation for minimizing cellular damage, auto- and fluorochrome fluorescence for locating and characterizing cells, and Nomarski contrast for highlighting taxonomic features (Lovejoy et al. 1993).

Predator populations. Several predator populations, including heterotrophic flagellates ( 2 to $10 \mu \mathrm{m}$ ), ciliates (15 to $35 \mu \mathrm{m}$ ) and tintinnids, were identified and monitored during the weeklong experiment. However, as it has already been shown that ciliates play a major role in controlling bacteria, heterotrophic flagellates and <5 $\mu \mathrm{m}$ phyioplankion population dynamics (Mostajir et al. 1999), only ciliate abundances at 09:00 h are presented here. Estimates of ciliate abundance were made with a Zeiss inverted microscope using $100 \mathrm{mI}$ water samples that had been preserved with acid Lugol (0.4\% final conc.) and sedimented for $24 \mathrm{~h}$.

Statistical analysis. A 1-way analysis of variance (ANOVA) with UVB treatment as the grouping factor was performed on each data set for each sampling time. When significant differences occurred, Bonferroni adjusted pairwise comparisons were used, as well as the Dunnett's test with NUVB treatment acting as the control group. For the Peell for phytoplankton $<5 \mu \mathrm{m}$, an ANOVA followed by a Tukey test (HSD: honestly significant difference) were performed. The probability values ( $p$ ) given hereafter are indicative of significant results for these statistical tests.

\section{RESULTS}

\section{Temperature, irradiance and nutrients}

During the $7 \mathrm{~d}$ of the experiment, the water temperature varied from 8.5 to $11.3^{\circ} \mathrm{C}$ with no significant differences between the tanks (Belzile et al. 1998). During the experiment, 3 successive periods were distinguished according to the incident irradiance: 2 sunny days, followed by 3 cloudy days, and finally 2 more sunny days (Fig. 2A,B,C). Only about $40 \%$ of the incident irradiance reached the water surface of the mesocosms due to shading effects (see Belzile et al. 1998 for details). The UVB lamps provided daily unweighted increased UVB doses of $40.5 \mathrm{~kJ} \mathrm{~m}^{-2}$ (LUVB) and $59.2 \mathrm{~kJ} \mathrm{~m}^{-2}$ (HUVB) at the water surface of the mesocosms. Fig. 2D shows the average UV radiation intensities just below the water surface calculated for a sunny day at noon. Biological weighting functions (BWFs) were applied because the experimental lamps and the sun have different spectral shapes with respect to UVB. The results from application of some wellknown BWFs to the spectral irradiance presented in Fig. 2D are illustrated in Table 1 (Cullen et al. 1992, Behrenfeld et al. 1993, Boucher \& Prézelin 1996). For a sunny day at noon, the UV irradiance in LUVB and HUVB treatments was 1.10 - and 1.15-fold higher,

Table 1. Relative irradiance increases provided by the lamps, for low (LUVB) and high (HUVB) ultraviolet-B enhancements, just below the water surface on a sunny day around noon compared to relative increases of incident irradiance associated with ozone depletion over Antarctica. These increases have been calculated from data presented in Fig. 2D. Spectral irradiances were weighted with the biological weighting function (BWF) for inhibition of photosynthesis in the temperate latitude diatom Phaeodactylum sp. (Cullen et al. 1992), the 'best fit' action spectrum for photoinhibition (Behrenfeld et al. 1993) and the daily averaged BWF for the in situ inhibition of primary production in a natural community of Antarctic diatoms (Boucher \& Prézelin 1996). The data for McMurdo Station are from Cullen \& Neale (1997) and correspond to a decrease of ozone thickness from 350 to $175 \mathrm{DU}$

\begin{tabular}{|lccc|}
\hline & $\begin{array}{c}\text { Incident solar } \\
\text { irradiance at } \\
\text { McMurdo }\end{array}$ & LUVB & HUVB \\
\hline $\begin{array}{l}\text { Unweighted UV } \\
\text { BWF for inhibition of }\end{array}$ & 1.06 & 1.10 & 1.15 \\
photosynthesis & 1.24 & 1.75 & 2.10 \\
$\begin{array}{l}\text { (Cullen et al. 1992) } \\
\text { BWF for photoinhibition } \\
\text { (Behrenfeld et al. 1993) }\end{array}$ & - & 3.26 & 4.31 \\
$\begin{array}{l}\text { BWF for in situinhibition } \\
\text { of photosynthesis } \\
\text { (Boucher \& Prézelin 1996) }\end{array}$ & 3.61 & 4.81 \\
\hline
\end{tabular}


respectively, relative to the NUVB. These values increased to $1.75-3.61$ (LUVB) and 2.10-4.81 (HUVB) when weighted with 3 BWFs for inhibition of photosynthesis (Table 1). The daily UVB enhancement was
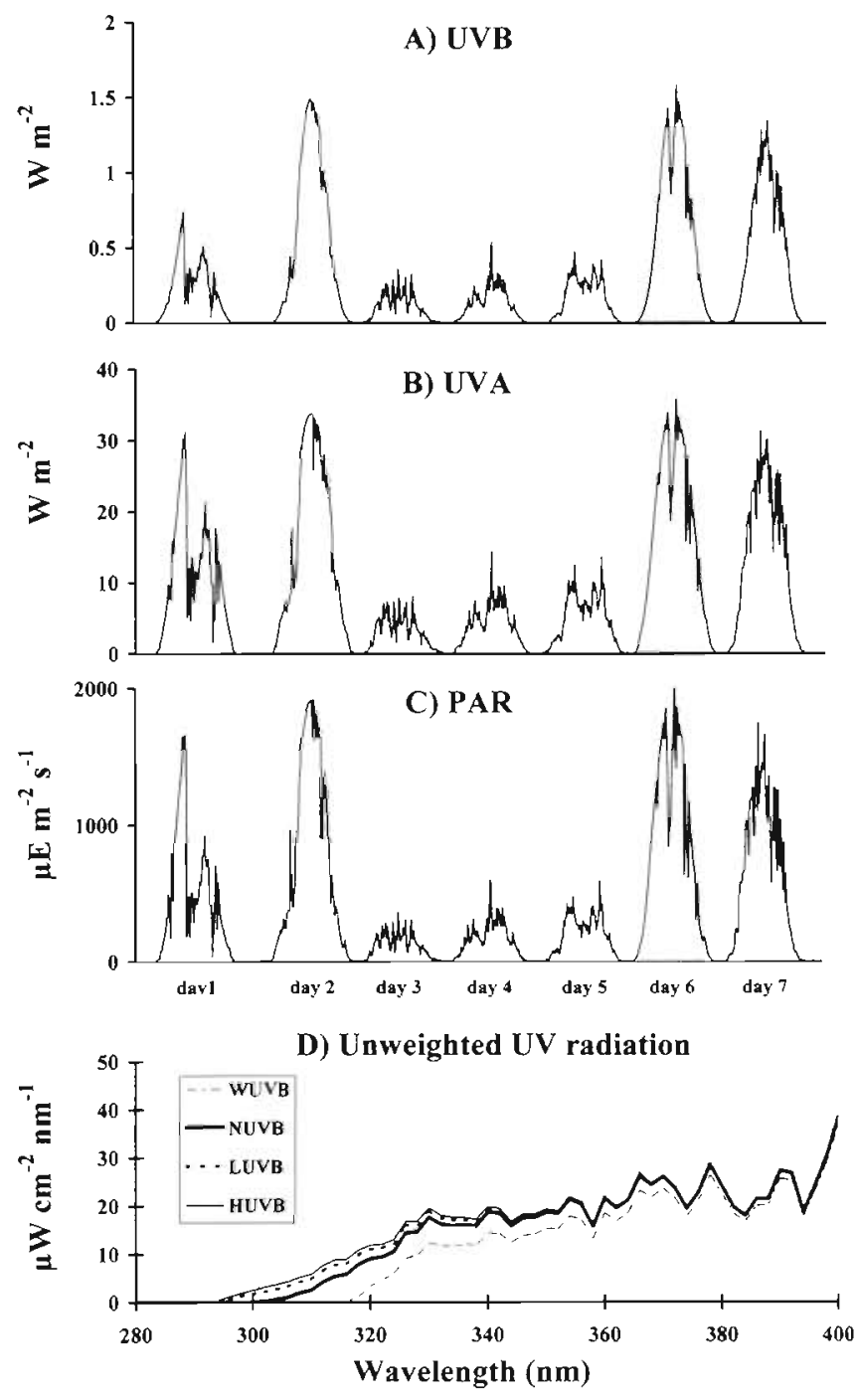

Fig. 2. Incident irradiance recorded every 10 min during the experiment. (A) Ambient ultraviolet-B (UVB) (280 to $320 \mathrm{~nm}$ ), (B) ambient UVA (320 to $400 \mathrm{~nm})$, (C) photosynthetically available radiation (PAR: 400 to $700 \mathrm{~nm}$ ) and (D) unweighted UV radiation intensities just below the water surface calculated for a sunny day at noon for 4 treatments of without UVB (WUVB), natural UVB (NUVB), low UVB enhancement (LUVB) and high UVB enhancement (HUVB). It should be noted that the irradiance in the WUVB treatments was calculated by multiplying the irradiance in NUVB by the transmission spectra of the Mylar sheet as measured by a spectrophotometer Contrary to the NUVB treatment, no dummy lamps were installed over the WUVB mesocosms to compensate for the $\sim 10 \%$ reduction of UVA and PAR (not measured) by the Mylar sheet. Consequently, $11 \%$ was added to the Mylar transmission spectra for wavelengths between 320 and

$700 \mathrm{~nm}$ in order to obtain a transmission of 1 at $700 \mathrm{~nm}$ much higher than that presented in Fig. 2D and Table 1 because the UVB lamps provided a constant UVB intensity throughout the entire 09:00 to $17: 30 \mathrm{~h}$ period, independently of weather conditions. For example, the daily enhancement at $305 \mathrm{~nm}$ for the LUVB treatments corresponded to $7-13$ and $28-51$ fold increases during sunny and cloudy days, respectively. For the HUVB treatments, this daily enhancement represented a $10-18$ and 40-74 fold increase during sunny and cloudy days, respectively. The $K_{d}$ of PAR ( 400 to $700 \mathrm{~nm}$ ) in the mesocosms was $1.46 \mathrm{~m}^{-1}$ and only $3.7 \%$ of the surface PAR reached the bottom of the mesocosms. In the St. Lawrence Estuary, $K_{d}$ (PAR) ranged between 0.29 and $0.53 \mathrm{~m}^{-1}$, corresponding to $1 \%$ surface PAR at 8.6 and $16.0 \mathrm{~m}$ depths in July (Levasseur et al. 1984). The water mass in these mesocosms thus simulated the euphotic zone. The rapid attenuation of the shorter wavelengths with depth provided organisms a refuge from harmful radiation. For instance, as little as $14 \mathrm{~cm}$ below the water surface the planktonic cells in the mesocosms were subjected to only half of the incident UVB but received $81 \%$ of surface PAR (Belzile et al. 1998). It is acknowledged that the lamps provided an increase in the daily UVB dose much higher than would be expected for the projected decreases in stratospheric ozone. Similarly, the UVB enhancement produced unnatural ratios of UVB: UVA:PAR, especially in the early morning and late afternoon.

Nitrate concentration decreased from Day 1 to Day 3 in all treatments, from 10 to $<0.9 \mu \mathrm{mol} \mathrm{l}^{-1}$ (Fig. 3A). Nitrate was depleted after Day 3. Ammonium concentrations increased in all treatments from $0.10 \mu \mathrm{mol} \mathrm{l}^{-1}$ on Day 3 to $0.28 \mu \mathrm{mol} \mathrm{l}^{-1}$ on Day $4(09: 00 \mathrm{~h})$. Thereafter, ammonium concentrations decreased until the end of the experiment to values never lower than $0.04 \mu \mathrm{mol}$ $\mathrm{I}^{-1}$, but did not show any consistent pattern with the treatments (Fig. 3B).

\section{Community composition of $<5 \mu$ m phytoplankton}

Using the microscopic method explained previously in conjunction with classical phase contrast microscopic observations of phytoplankton $<5 \mu \mathrm{m}, 2$ populations were identified. One is a population of yellow-brown and parietal plastidian cells with 2 unequal smooth flagella located on both sides of an appendage identified as haptonema. This flagella system is characteristic of the Oligomastigophorean flagellate class of Prymnesea (=Haptophyceae, Christensen 1962 or Prymnesiophyceae, Hibberd 1976). The second one is a population of Chrysophyceae (Ochromonas sp.). Based on flow cytometric analysis and microscopic observations, Prymnesiophyceae ranged in size between 2.7 and 

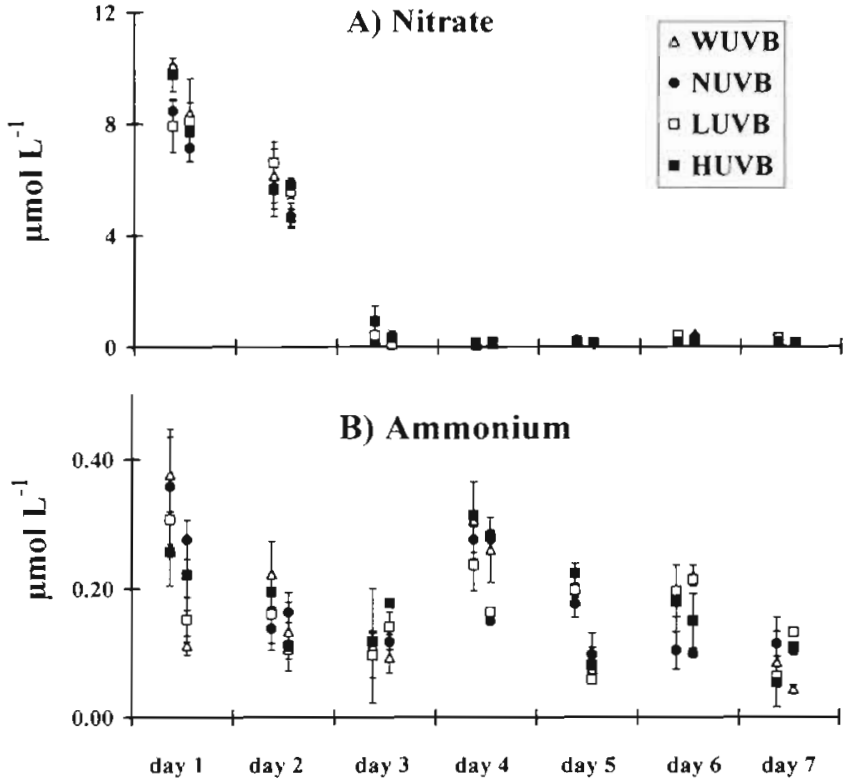

Fig. 3. Variations in the concentrations of (A) nitrate and (B) ammonium at $09: 00$ and $13: 00 \mathrm{~h}$ during the experiment under varying conditions of UVB radiation. Bars represent the range of the observations

$4 \mu \mathrm{m}$ and represented more than $94 \%$ of the cell numbers of phytoplankton $<5 \mu \mathrm{m}$. Chrysophyceae were larger and ranged in size between 4 and $5 \mu \mathrm{m}$.

\section{Population dynamics and cell size changes of Prymnesiophyceae}

Following an apparent adaptation phase during the first $8 \mathrm{~h}$ of the experiment, the Prymnesiophycean population generally increased in abundance between Day 1 and Day 3 (Fig. 4A), coinciding with decreasing nitrate concentrations (Fig. 3A). Abundances were relatively constant and similar for all treatments during Days 4 to 6 , and then decreased slightly towards the end of the experiment when significant differences were noted between treatments. Prymnesiophycean abundances were significantly higher in the HUVB and LUVB treatments at $09: 00 \mathrm{~h}$ on Day 7 compared to the NUVB and WUVB treatments $(p<0.05)$.

As a general trend of Prymnesiophyceae cell size (CS) changes, CS continuously increased during the daytime to reach maximum values at $17: 00 \mathrm{~h}$, and then constantly decreased during the nighttime to attain minimal values at $05.00 \mathrm{~h}$ (Fig. 4B). Following an identical diel variation of $C S$ in all treatments during sunny Days 1 to 2, Day 3 was marked by a drastic decline in CS in all treatments during nighttime. CS within the Prymnesiophycean population was higher at 17:00 h than at 09:00 h during Days 4 to 7 , suggesting the con- tinuation of the diel periodicity observed during Days 1 to 3 . However, the CS diel pattern on Days 4 to 7 differed from the earlier pattern (i.e. Days 1 to 3 ) in that differences between treatments were occurring. The $\mathrm{CS}$ for the cohort recorded at 17:00 $\mathrm{h}$ increased in HUVB, remained relatively stable in LUVB, decreased slightly in NUVB and declined sharply in WUVB treatments (Fig. 4B). CS were significantly different on Day 7 ( $p<0.001)$ for all treatments. The CS variations showed that under UVB-enhanced conditions, Prymnesiophyceae cells were larger than those in natural and UVB-excluded conditions. It should be mentioned that during the last $3 \mathrm{~d}$ of the experiment, significantly higher CS under HUVB treatments relative to all other treatments were observed not only at $17: 00 \mathrm{~h}$ but also at 09:00 h (for Days 5 and 7, p $<0.001$ and for Day $6, p<$ 0.005). The same tendency under LUVB treatments appeared during the last $2 \mathrm{~d}$ of the experiment (Fig. 4B). Mean cell diameters ( \pm range of the observations) of Prymnesiophyceae under WUVB, NUVB, LUVB and HUVB treatments on Day 7 at 17:00 h were estimated at $2.9 \pm 0.1,3.2 \pm 0.2,3.4 \pm 0.0$ and $3.7 \pm$ $0.0 \mu \mathrm{m}$, respectively (maximum difference of $0.8 \mu \mathrm{m}$ ).

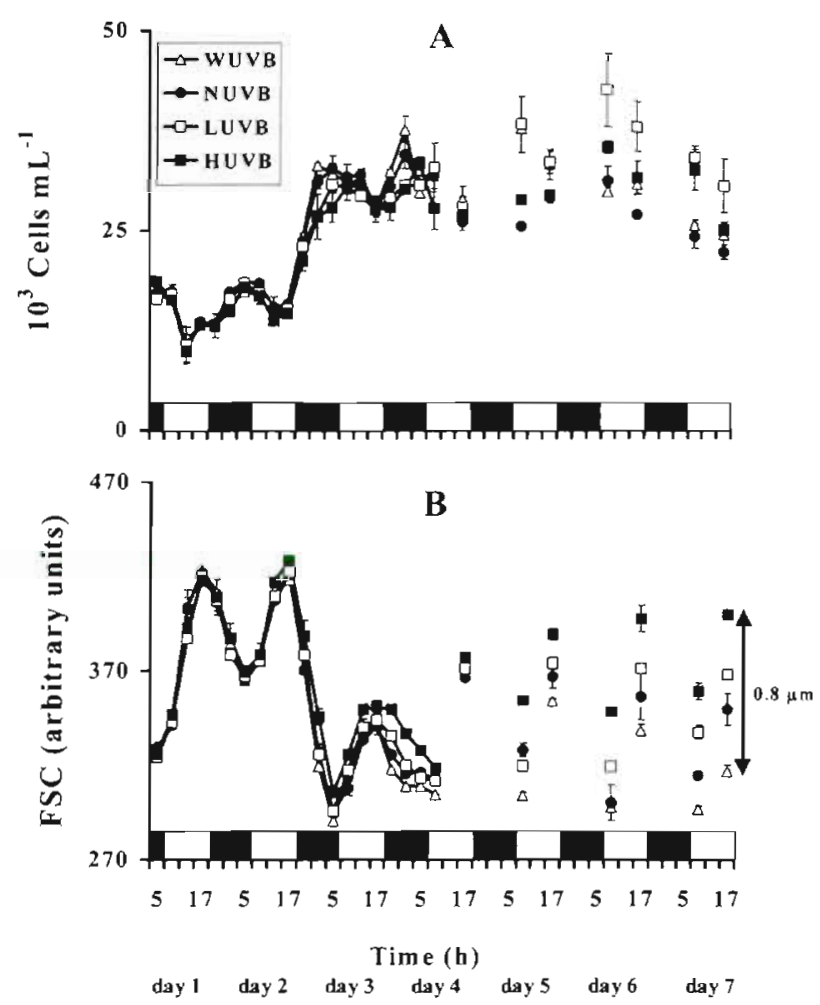

Fig. 4. Time series of Prymnesiophyceae for $1 \mathrm{wk}$ showing 3 diel cycles ( $72 \mathrm{~h}$ with 4 h temporal resolution): (A) abundances $\left(10^{3}\right.$ cells $\left.\mathrm{ml}^{-1}\right)$ and (B) forward scatter (FSC, cell size). Alternating white and black bars designate day 109:00, 13:00 and 17:00 h) and night (21:00, 01:00 and 05:00 h). Bars represent the range of the observations 
Assuming a spherical cell shape, these diameters correspond to volumes of $12.8,17.2,20.6$ and $26.5 \mu^{3}$ for WUVB, NUVB, LUVB and HUVB treatments, respectively.

\section{Specific rate of photosynthesis $\left(\mathrm{P}^{\text {cell }}\right)$ of phytoplankton $<5 \mathrm{\mu m}$}

Following a slight decrease during Days 1 to 2, pcell of phytoplankton $<5 \mu \mathrm{m}$ increased slightly during Days 2 to 4 , with a higher rate during Days 4 to 5 , and then decreased till the end of the experiment (Fig. 5).

During Day 5, the Pcell in the WUVB $\left(1.21 \mathrm{pg} \mathrm{C}\right.$ cell $^{-1}$ $\mathbf{h}^{-1}$ ) and NUVB (1.14 pg C cell ${ }^{-1} \mathrm{~h}^{-1}$ ) treatments were significantly $(\mathrm{p}<0.05)$ higher than in LUVB $(0.57 \mathrm{pg} C$ cell $\left.{ }^{-1} \mathrm{~h}^{-1}\right)$ and HUVB (0.62 pg C cell $\left.{ }^{-1} \mathrm{~h}^{-1}\right)$. From Day 5 until the end of the experiment, $\mathrm{P}^{\mathrm{cell}}$ generally decreased in all treatments (except for a slight increase of $0.03 \mathrm{pg} \mathrm{C}$ cell ${ }^{-1} \mathrm{~h}^{-1}$ for HUVB from Day 6 to Day 7 ). During Days 6 and 7 , pell in the WUVB treatment were significantly $(\mathrm{p}<0.05)$ higher than in the presence of UVB, including natural conditions. During the last $3 d$ of the experiment, the $\mathrm{P}^{\text {cell }}$ of phytoplankton $<5 \mu \mathrm{m}$ under both enhanced UVB treatments were 48 to $73 \%$ lower than in the UVB-excluded conditions. During the same period, a reduction of 4 to $47 \%$ of $\mathrm{P}^{\text {cell }}$ was also observed in NUVB compared to WUVB treatments.

As mentioned above, the phytoplankton $<5 \mu$ m were largely dominated by Prymnesiophyceae (more than $94 \%$ ) and thus the contribution of Chrysophyceae (4 to $5 \mu \mathrm{m}$ ) to the pcell of phytoplankton $<5 \mu \mathrm{m}$ can be assumed to be minor.

\section{Dynamics of potential predator population}

Ciliate populations were dominated by the following species: Strobilidium spiralis, Strombidium acutum, Strobilidium epacrum, Lohmaniella oviformis, Askenasia sp., Uronema marinum and Laboea sp. (Mostajir et al. 1999). The majority of the ciliate population ranged in size between 17 and $22 \mu$ m (mean 19.2, $\mathrm{n}=801$ ). In all treatments, their abundances were minimal until Day $3\left(<1\right.$ cell $\left.\mathrm{ml}^{-1}\right)$, and then increased progressively till the end of the experiment when notable differences between treatments were observed (Fig, 6). Ciliate numbers on Day 7 in all treatments were indeed significantly ( $p<0.001$ ) different from each other, in a decreasing order $(19,16,10$ and 5 cell ml-1 for WUVB, NUVB, LUVB and HUVB, respectively) that corresponded to the increasing exposure to UVB radiation.

As an attempt to elucidate the predator-prey interaction, the relationship between Prymnesiophyceae size and ciliate abundance in different UVB treatments

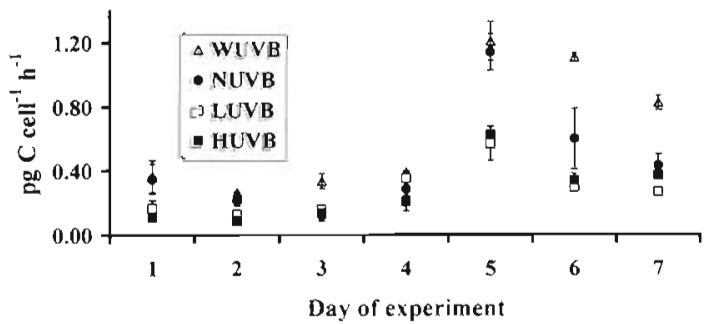

Fig. 5. Specific rate of photosynthesis ( $\mathrm{P}^{\mathrm{cell}}$ ) of phytoplankton $<5 \mu \mathrm{m}$ under varying regimes of UVB. Bars represent the range of the observations

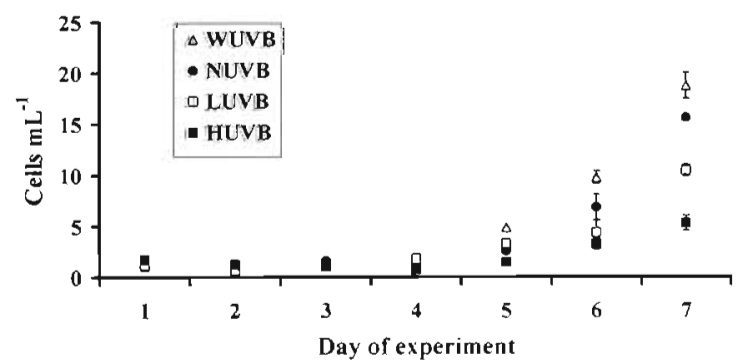

Fig. 6. Temporal variations of ciliate abundances (cells $\mathrm{ml}^{-1}$ ) during a week long experiment under 4 UVB treatments. Bars represent the range of the observations

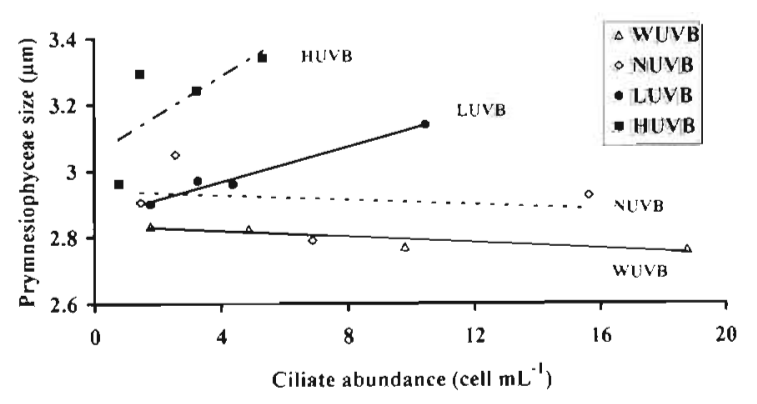

Fig. 7. Relationship between Prymnesiophyceae sizes and ciliate abundances during the last $4 \mathrm{~d}$ of the experiment

during the last $4 \mathrm{~d}$ of the experiment, when the differences were more pronounced between treatments, is shown in Fig. 7. The correlation coefficients are significant for WUVB and LUVB at the $p<0.1$ and $p<0.05$ levels, respectively.

\section{DISCUSSION}

\section{Cell size variations and photosynthetic capacity of Prymnesiophyceae during short-term (3 d) and long-term (7 d) UVB exposure}

The Prymnesiophycean population in all mesocosms exhibited similar diel variation in their cell size (CS), 
with maxima at 17:00 $\mathrm{h}$ and minima at 05:00 $\mathrm{h}$. during the first $3 \mathrm{~d}$ of the experiment (short-term) characterized by a high sampling resolution (every $4 \mathrm{~h}$ ). It would be difficult to identify with certainty any particular environmental cause for a very large decrease in CS on Day 3. However, as an altemative cause, a large decrease in incident irradiance during Day 3 (Fig. 2) coupled with a well-mixed mesocosm would result in the subsaturation of photosynthesis over most of the day. By the end of the day, the cells would likely not have sufficient photosynthate to create 2 large cells during nocturnal cell division, but may be able to create 2 smaller cells (M. Behrenfeld, as one of the 4 reviewers). The Prymnesiophyceae population during Days 3 to 7 (long-term) always exhibited highest CS in the late afternoon $(17: 00 \mathrm{~h})$ and lowest CS in the early morning $(09: 00 \mathrm{~h})$ in all treatments, despite the low sampling resolution $(09: 00$ and $17: 00 \mathrm{~h})$ and the occurrence of differences between treatments. These observations indicate the occurrence of synchronic cell division within the Prymnesiophycean population during the nighttime and the relative resistance of this apparent endogenous rhythmicity, frequent in phytoplankton communities, not only to a short-term ( $3 \mathrm{~d}$ ) but also to a long-term ( 7 d) exposure to UVB radiation. Synchronized cell division is well known in the aquatic environment for both phytoplankton (Pollingher \& Serruya 1976, Heller 1977, Taylor 1980, Frempong 1982) and bacterioplankton (Sime-Ngando et al. 1991).

Prymnesiophyceae CS was significantly larger in the enhanced UVB than in the natural and UVB excluded treatments after $7 \mathrm{~d}$ of exposure. This increase in CS for a natural planktonic community agrees with results from earlier laboratory studies (Behrenfeld et al. 1992. Van Donk \& Hessen 1995, Buma et al. 1996).

One potential cause of cell enlargement in this experiment could be due to the perturbation of the cell cycle under UVB enhancement. The diel pattern in CS contrasted with the circadian variability in cell abundance that was generally higher during the night than during daytime (from 05:00 to 17:00 h, Fig. 4). This clearly means that during this experiment, UVB apparently affected the number of divisions but not the frequency or rythmicity. To elucidate the change in the cell division rate of Prymnesiophyceae, the rate of change for this population (reflecting mortality, grazing and division rates) was calculated. The results (not shown) do not show any consistent pattern with treatment as this population was grazed under different pressures (see below: 'Predator-prey interactions under UVB exposure'). Prymnesiophyceae such as Emiliana huxleyi are sensitive to UVB radiation, probably due to its effects on the cell cycle related to nuclear DNA damage (Gieskes \& Buma 1997). The DNA damage can generally cause inhibition of DNA replication which is a precondition for cell division (Buma et al. 1996). Karentz et al. (1991) found an interspecific decrease in UV sensitivity with increasing cell volume and suggested that increased cell volume may protect DNA by increasing the pathlength for UVB radiation through the cell. However, Laurion \& Vincent (1998) have recently demonstrated that CS is not a good index of UV sensitivity. UVB radiation may inhibit steps in the cell cycle, notably the retardation of the entry of DNA replication in the $\mathrm{S}$ phase (Setlow et al. 1963, Buma et al. 1996), resulting in a continued cell growth without division (see Behrenfeld et al. 1992). The same process was reported for Cyclotella $\mathrm{sp}$. (Buma et al. 1997), supporting the hypothesis that DNA is one of the primary targets of UVB radiation (Karentz et al. 1991, Buma et al. 1995, 1996). At the end of the experiment, the higher Prymnesiophycean CS under UVB enhancement compared to natural conditions at both dawn and dusk (Fig. 4B) may indicate that a portion of the population was not dividing. This portion of cells grows to a larger size in preparation for division, but then does not divide. Although there are no direct measurements of DNA damage in this experiment, the findings, lllustrating Prymnesiophyceae cell enlargement under UVB stress, could similarly reflect the retardation of the cell cycles in the $\mathrm{S}$ phase. Buma et al. (1996) have shown for the diatom Cyclotella sp. that decreased division rates under UVB enhancement were typically accompanied by an increase in CS. For a long time, it has been known that certain types of UV damage could decouple cell growth and division processes, resulting in the enlargement of cells of some protistan taxa. For example, it has been shown that exposure to UV radiation perturbed cell division in a laboratory culture of the ciliate Paramecium caudatum (Hinrichs 1928, Karentz et al. 1994 and references therein). This provoked the formation of giant or monster cells, partly due to the induction of adducts involved in DNA repair mechanisms or due to the accumulation of substances that could no longer be discharged from the cell.

The second potential cause of cell enlargement in this experiment could be due to the change in photosynthetic capacity. Although the impact of UVB radiation on the photosynthetic capacity is not discussed in detail in the present paper, these data are used firstly to explain Prymnesiophyceae cell enlargement and secondly to elucidate the ecological implications of the photosynthetic capacity of Prymnesiophyceae on predator-prey interactions. A decrease in photosynthetic rates of Prymnesiophyceae could cause a decrease in cell division rates and changes in CS. A higher Pcell of smaller Prymnesiophyceae relative to all other conditions at the end of the experiment is illustrated in Fig. 5. Comparable results about the reduc- 
tion of primary production have already demonstrated the sensitivity of phytoplankton (including Prymnesiophyceae) to UVB radiation, which is known to reduce the rate of primary production (Smith et al. 1980 Cullen \& Lesser 1991, Smith et al. 1992, Vincent \& Roy 1993). The results on the reduction of the $\mathrm{P}^{\mathrm{cell}}$ under natural and enhanced UVB presented here come from the samples that were incubated at the water surface of the mesocosms, where the UVB doses were higher than those received by organisms present in the water column. Due to the rapid attenuation of the shorter wavelengths with depth in the mesocosms, the UVB doses diminished by $50 \%$ at $14 \mathrm{~cm}$ below the water surface in the mesocosms. At $1 \mathrm{~m}$ depth, planktonic cells received $23 \%$ of surface PAR, but only $0.6 \%$ of surface UVB at $305 \mathrm{~nm}$. Given such optical characteristics and that the water was continuously mixed, the water column of the mesocosm simulated the euphotic zone. Planktonic organisms would have been able to repair UVB damage in the deeper waters of the mesocosms, as well as undertake nighttime repair processes. Therefore, results of $\mathrm{P}^{\text {cell }}$ reduction from incubations at the water surface in the presence of UVB are overestimated compared to the average situation in the mesocosm. Compared to the WUVB treatment, these rates clearly demonstrate the sensitivity of phytoplankton $<5 \mu \mathrm{m}$ to UVB and reflect their physiological condition under different UVB doses. This highlights the role of vertical mixing in UVB enhancement studies. Vertical mixing in natural aquatic systems transports organisms to deeper water, permitting them to repair UVB damage. This could also explain the nonsignificant effect of UVB treatments for the synchronized diel variability observed during this experiment.

Nutrient limitation can also play a role in CS changes. During our experiment, a parallel study by Fauchot (1998) showed that there was no significant difference between treatments for nitrate and ammonium concentrations, although ammonium and urea uptake became important after nitrate exhaustion on Day 3. Although there is no measurement of other nutrients $\left(\mathrm{PO}_{4}{ }^{3-}\right.$ and trace elements) that could limit algal growth, the work of Fauchot (1998) suggests that Prymnesiophyceae were not limited by nitrates, but were growing on regenerated supplies such as ammonium. Hence, CS changes observed for Prymnesiophyceae were not due to nutrient limitation but rather to the direct effect of UVB radiation.

\section{Predator-prey interactions under UVB exposure}

In aquatic systems, the link between primary production, bacteria and higher trophic levels is generally mediated by microzooplankton (Azam et al. 1983).
Among Protozoa, ciliates are able to play a pivotal role in marine food webs. Through predation, ciliates can regulate the populations of autotrophic picoplankton ( $\leq 2 \mu \mathrm{m}$ ) (Rassoulzadegan et al. 1988, Bernard \& Rassoulzadegan 1990) and bacterioplankton (Fenchel 1980, Rivier et al. 1985, Sherr \& Sherr 1987). They can also transfer the bulk of both matter and energy fluxes from lower trophic levels, i.e. pico- and nanoplankton $(0.2$ to $20 \mu \mathrm{m})$, to higher ones such as metazoan zooplankton (Stoecker \& Egloff 1987, Wiadnyana \& Rassoulzadegan 1989, Jonsson \& Tiselius 1990, Dolan 1991, Hartmann et al. 1993, Sime-Ngando et al. 1995), coral (Ferrier-Pagès et al. 1998), oyster (Le Gall et al. 1997) and fish larvae (De Mendiola 1974).

Although the negative impact of UVB on Prymnesiophycean cell division was obvious (see above), their abundances paradoxically increased significantly with increasing exposure to UVB (Day 7, 09:00 h, p < 0.05). This contrasts with the pattern in ciliate density which decreased with increasing exposure to UVB $166 \%$ lower under HUVB relative to NUVB, Fig. 6), indicating the prevalence of the predation pressure from ciliates on Prymnesiophyceae growth during this experiment.

The negative effect of UVB enhancement on prey (phytoplankton) can therefore be masked by trophic relationships such as predator-prey interactions. The negative effect of UVB on predator populations (ciliates) induces a positive feedback between enhanced UVB and prey abundances. Hence, in studies concerning the effects of UVB on aquatic systems, trophic interactions should be involved with the other studied parameters, as suggested previously by Mostajir et al. (1999).

Another aspect of predator-prey interactions is related to the preferential prey size. The main feature of the particle-size model developed by Sheldon et al. (1972) and modified by Azam et al. (1983) is that organisms tend to utilize particles 1 order of magnitude smaller than themselves. Generally, nanociliates $(<20 \mu \mathrm{m})$, which dominated the ciliate community during this study, selectively remove the largest bacteria (Bernard \& Rassoulzadegan 1990, Christaki et al. 1998) and picophytoplankton (including cyanobacteria) ranging in size around $1 \mu \mathrm{m}$ (Mostajir et al. 1998). A significant relationship between the diel vertical distribution of planktonic ciliates and zeaxanthin, a pigment bioindicator of cyanobacteria, was reported in the surface layer of the NW Mediterranean (Perez et al. in press). In our experiment, the cyanobacteria were absent and ciliates, ranging in size between 17 and $22 \mu \mathrm{m}$ (mean diameter $=19.2 \mu \mathrm{m}, \mathrm{n}=801$ ), likely grazed on heterotrophic bacteria $(<1 \mu \mathrm{m})$, small phytoplankton $(<5 \mu \mathrm{m})$ and heterotrophic nanoflagellates (2 to $10 \mu \mathrm{m}$ ) (Mostajir et al. 1999). Fig. 7 shows that 
in UVB-excluded treatments where the highest ciliate abundances were recorded, the Prymnesiophyceae population was exclusively represented by the smallest cells. Apart from a probable direct UVB negative effect on ciliate abundance, one of the reasons for the higher ciliate abundance under WUVB and NUVB conditions (relative to enhanced UVB treatments) could be the relatively greater availability and quality of the Prymnesiophyceae prey (dividing more rapidly and producing more carbon) in the preferred size range. It is also possible that a change in food quality of the Prymnesiophyceae, especially the fatty acid composition, might have been affected by UVB exposure (Goes et al. 1994, De Lange \& Van Donk 1997). The negative significant slope ( $p<0.1$ ) of the predator and prey-size relationship in WUVB conditions suggests that smaller Prymnesiophyceae were likely adequate for ciliate development (Fig. 7). The change in slope of this relationship from negative to positive as a function of increased UVB doses demonstrates the importance of prey size for the development of ciliates.

In summary, the results of this study suggest that enhanced UVB can provoke the retardation of cell division and inhibition of the Pcell of phytoplankton, which causes Prymnesiophyceae CS enlargement. The ciliate population decreased significantly in number under UVB enhancement. The reduction of ciliate abundance can be attributed to a direct or an indirect (via prey) effect of enhanced UVB exposure. CS enlargement, as well as probably a change in food quality (fatty acid composition) of prey, could result in food limitation for the ciliate population and thus partially explain their decrease in abundance. The ciliates transfer the major flux of matter and energy from the lower trophic levels to higher ones and a slight perturbation in such transfers will have an important ramification throughout the marine food web with considerable ecological consequences. We conclude that in order to predict the effect of enhanced UVB at the ecosystem level, trophic interactions between different trophic levels should definitely be considered.

Acknowledgements. We thank J. Bouchard for her help in cytometric analyses, D. Bourget and N. Lafontaine for nutrient analyses and $L$. Zudaire for data visualization. We wish to thank $M$. Behrenfeld as well as 3 other anonymous reviewers for useful suggestions. This work was supported by NSERC of Canada, Fonds FCAR of Québec and FODAR (University of Québec). This investigation is a contribution to the research programs of the Groupe de Recherche en Environnement Côtier

\section{LITERATURE CITED}

Azam F, Fenchel T, Field JG, Gray JS, Meyer-Reil LA, Thingstad $F$ (1983) The ecological role of water-column microbes in the sea. Mar Ecol Prog Ser 10:257-263

Behrenfeld MJ, Hardy JT, Lee H II (1992) Chronic effects of ultraviolet-B radiation on growth and cell volume of Phaeodactylum tricornutum (Bacillariophyceae). J Phycol 28:725-760

Behrenfeld MJ, Chapman JW, Hardy JT, Lee II H (1993) Is there a common response to ultraviolet-B radiation by marine phytoplankton? Mar Ecol Prog Ser 102:59-68

Belzile C, Demers S, Lean DRS, Mostajir B, Roy S, de Mora S, Gosselin M, Bird D, Chanut JP, Levasseur M (1998) An experimental tool for the study of the effects of ultraviolet radiation on planktonic communities: a mesocosm approach. Environ Technol 19:667-682

Bernard C. Rassoulzadegan F (1990) Bacteria or microflage]lates as a major food source for marine ciliates: possible implications for the microzooplankton. Mar Ecol Prog Ser 64:147-155

Boucher NP, Prézelin B (1996) An in situ biological weighting function for UV inhibition of phytoplankton carbon fixation in the Southern Ocean. Mar Ecol Prog Ser 144: $223-236$

Buma AGJ, Van Hannen EJ, Veldhuis MJW, Roza L, Gieskes WWC (1995) Monitoring UV-B induced DNA damage in individual diatom cells by immunofluorescent thymine dimer detection. J Phycol 31:314-321

Buma AGJ, Zenmelink HJ, Sjollema K, Gieskes WWC (1996) UVB radiation modifies protein and photosynthetic pigment content, volume and ultrastructure of marine diatoms. Mar Ecol Prog Ser 142:47-54

Buma AGJ, Engelen AH, Gieskes WWC (1997) Wavelengthdependent induction of thymine dimers and growth rate reduction in the marine diatom Cyclotella sp. exposed to ultraviolet radiation. Mar Ecol Prog Ser 153:91-97

Calkins J, Thordardottier T (1980) The ecological significance of solar UV radiation on aquatic organisms. Nature 283: 563-566

Christaki U, Dolan JR, Pelegri S, Rassoulzadegan F (1998) Consumption of picoplankton-size particles by marine ciliates: effects of physiological state of the ciliate and particle quality. Limnol Oceanogr 43:458-464

Christensen T (1962) Alger. In: Bocher TW et al. (eds) Botanik, Vol 2. Munksgaard, Copenhagen

Cullen JJ, Lesser MP (1991) Inhibition of photosynthesis by ultraviolet radiation as a function of dose and dosage rate: results for a marine diatom. Mar Biol 111:183-190

Cullen JJ, Neale PJ (1997) Biological weighting function for describing the effects of ultraviolet radiation on aquatic systems. In: Häder DP (ed) The effects of ozone depletion on aquatic ecosystems. Landes RG, Georgetown, p $97-118$

Cullen JJ, Neale PJ, Lesser MP (1992) Biological weighting function for the inhibition of phytoplankton photosynthesis by ultraviolet radiation. Science 258:646-650

Davidson AT, Marchant HJ, de la Mare WK (1996) Natural UVB exposure changes the species composition of Antarctic phytoplankton in mixed culture. Aquat Microb Ecol 10 : $299-305$

De Lange HJ, Van Donk E (1997) Etfects of UVB irradiated algae on life history traits of Daphnia pulex. Freshw Biol 38:711-720

De Mendiola BR (1974) Food of the larval Anchoveta Engraulis ringens. In: Blaxter JHS (ed) The early life history of fish. Springer-Verlag, Berlin, p 277-285

Dolan JR (1991) Microphagous ciliates in mesohaline Chesapeake Bay waters: estimates of growth rates and consumption by copepods. Mar Biol 111:303-309

DuRand MD, Olson RJ (1998) Diel patterns in optical proper- 
ties of chlorophyte Nannochloris sp.: relating individual-cell to bulk measurements. Limnol Oceanogr 43: $1107-1118$

Fauchot J (1998) Influence du rayonnement ultraviolet-B sur l'utilisation de l'azote par un assemblage naturel phytoplanctonique. MSc thesis, Université du Québec à Rimouski, Québec

Fenchel T (1980) Relation between particle size selection and clearance in suspension-feeding ciliates. Limnol Oceanogr 25:733-738

Ferrier-Pagès C, Allemand D, Gattuso JP, Jaubert J, Rassoulzadegan F (1998) Microheterotrophy in the zooxanthellate coral Stylophora pistillata: effects of light and ciliate density. Limnol Oceanogr 43:1639-1648

Frempong E (1982) The space-time resolution of phased cell division in natural populations of the freshwater dinoflagellates Ceratium hirundinella. Int Rev Ges Hydrobiol 67: 323-339

Gieskes WWC, Buma GJ (1997) UV damage to plant life in a photobiologically dynamics environment: the case of marine phytoplankton. Plant Ecol 128:16-25

Goes JI, Handa N, Taguchi S, Hama T (1994) Effect of UV-B radiation on the fatty acid composition of the marine phytoplankter Tetraselmis sp.: relationship to cellular pigments. Mar Ecol Prog Ser 114:259-274

Hartmann HJ, Hassan T, Aleya L, Lair N (1993) Predation on ciliates by suspension-feeding calanoid copepod Acanthodiaptomus denticornis. Can J Fish Aquat Sci 50: 1382-1393

Heller MD (1977) The phased division of the freshwater dinoflagellate Ceratium hirundinella and its use as a method of assessing growth in natural populations. Freshw Biol 7:527-533

Hibberd DJ (1976) The ultrastructure and taxonomy of the Chrysophyceae and Prymnesiophyceae (Haptophyceae): a survey with some new observations on the ultrastructure of the Chrysophyceae. Bot J Linn 72:55-80

Hinrichs MA (1928) Ultra-violet radiation and division in Paramecium caudatum. Physiol Zol 1:394-415

Jokiel PL, York RH (1984) Importance of ultraviolet radiation in photoinhibition of microalgal growth. Limnol Oceanogr 29:192-199

Jonsson PR, Tiselius P (1990) Feeding behaviour, prey detection, and capture efficiency of the copepod Acartia tonsa feeding on planktonic ciliates. Mar Ecol Prog Ser 60:35-44

Karentz D, Cleaver JE, Mitchell DL (1991) Cell survival characteristics and molecular responses of Antarctic phytoplankton to ultraviolet-B radiation. J Phycol 27: 326-341

Karentz D, Bothwell ML, Coffin RB, Hanson A, Herndl GJ, Kilham SS, Lesser MP, Lindell M, Moeller RE, Morris DP, Neale PJ, Sanders RW, Weiler CS, Wetzel RG (1994) Impact of UV-B radiation on pelagic freshwater ecosystems: report of working group on bacteria and phytoplankton. In: Williamson CE, Zagarese HE (eds) Impact of UV-B radiation on pelagic freshwater ecosystems. Arch Hydrobiol Beih Ergebn Limnol 43:31-69

Kirk JTO, Hargreaves BR, Morris DP, Coffin RB, David B, Fredrickson D, Karentz D, Lean DRS, Lesser MP, Madronich S, Morrow JH, Nelson NB, Scully NM (1994) Measurements of UV-B radiation in two freshwater lakes: an instrument intercomparison. In: Williamson $C E$, Zagarese HE (eds) Impact of UV-B radiation on pelagic freshwater ecosystems. Arch Hydrobiol Beih Ergebn Limnol 43:71-99

Laurion I, Vincent FV (1998) Cell size versus taxonomic composition as determinants of UV-sensitivity in nat- ural phytoplankton communities. Limnol Oceanogr 43: $1774-1779$

Lean DRS, Burnison BK (1979) An evaluation of errors in the ${ }^{14} \mathrm{C}$ method of primary production measurement. Limnol Oceanogr 24:917-928

Le Gall S, Bel Hassen M, Le Gall P (1997) Ingestion of a bacterivorous ciliate by the oyster Crassostrea gigs: protozoa as a trophic link between picoplankton and benthic suspension-feeders. Mar Ecol Prog Ser 152:301-306

Levasseur M, Therriault JC, Legendre L (1984) Hierarchical control of phytoplankton succession by physical factors. Mar Ecol Prog Ser 19:211-222

Lovejoy C, Vincent W, Frenette JJ, Dodson JJ (1993) Microbial gradients in a turbid estuary: application of a new method for protozoan community analysis. Limnol Oceanogr 38:1295-1303

Mostajir B, Bustillos-Guzmán J, Claustre H, Rassoulzadegan F (1998) Pigment dynamics associated with the grazing of a ciliate and a flagellate feeding on a cyanobacteria. Oceanol Acta 21:581-588

Mostajir B, Demers S, de Mora S, Belzile C, Chanut JP, Gosselin M, Roy S, Fauchot J, Villegas PZ, Bouchard J, Bird D, Monfort P, Levasseur M (1999) Experimental test of the effect of ultraviolet- $B$ radiation in a planktonic community. Limnol Oceanogr 44:586-596

Neale PJ, Lesser MP, Cullen JJ (1994) Effects of ultraviolet radiation on the photosynthesis of phytoplankton in the vicinity of McMurdo station, Antarctica. In: Weiler CS, Penhale PA (eds) Ultraviolet radiation in Antarctica: measurements and biological effects. Antarctic Research Series Vol 62. Am Geophys Union, Washington, DC, p $125-142$

Parsons TR, Maita Y, Lalli CM (1984) A manual of chemical and biological methods for seawater analysis. Pergamon Press, Toronto

Perez MT, Dolan JR, Vidussi F, Fukai E (in press) Diel vertical distribution of planktonic ciliates within the surface layer of the NW Mediterranean (May 1995). Deep-Sea Res

Pollingher U, Serruya C (1976) Phased division of Peridinium cinctum $\mathrm{f}$. westii and the development of the bloom in Lake Kinneret (Israel). J Phycol 12:162-170

Rassoulzadegan F, Laval-Peuto M, Sheldon RW (1988) Partitioning of the food ration of marine ciliates between picoand nanoplankton. Hydrobiologia 159:75-88

Rex M, Harris NRP, von der Gathen $P$, Lehmann $R$, Braathen GO, Reimer E, Beck A, Chipperfield MP, Alfier R, Allaart M, O'Connor F, Dier H, Dorokhov V, Fast $H$, Gill M, Kyrö E, Litynska Z, Mikkelsen IbS, Molyneux MG, Nakane $H$, Notholt J, Rummukainen M, Viatte P, Wenger J (1997) Prolonged stratospheric ozone loss in the 1995-96 Arctic winter. Nature 389:835-838

Rivier A, Brownlee DC, Sheldon RW, Rassoulzadegan F (1985) Growth of microzooplankton: a comparative study of bactivorous zooflagellates and ciliates. Mar Microb Food Webs 1:51-60

Setlow RB, Swenson PA, Carrier WL (1963) Thymine dimers and inhibition of DNA synthesis by ultraviolet irradiation of cells. Science 142:1464-1465

Sheldon RW, Prakash A, Sutcliffe WH (1972) The size distribution of particles in the ocean. Limnol Oceanogr 17: $327-340$

Sherr EB, Sherr BF (1987) High rates of consumption of bacteria by pelagic ciliates. Nature 325:710-711

Sime-Ngando T, Bourdier G, Amblard C, Pinel-Alloul B (1991) Short-term variations in specific biovolume of different bacterial forms in aquatic ecosystems. Microb Ecol $21: 211-226$ 
Sime-Ngando T, Gosselin M, Roy S, Chanut JP (1995) Significance of planktonic ciliated protozoa in the lower St. Lawrence Estuary: comparison with bacterial, phytoplankton, and particulate organic carbon. Aquat Microb Ecol 9:243-258

Smith RC, Baker KS, Holm-Hansen O, Olson R (1980) Photoinhibition of photosynthesis in natural waters. Photochem Photobiol 31:585-592

Smith RC, Prézelin BB, Baker KS, Bidigare RR, Boucher NP, Coley T, Karentz D, Macintyre S, Matlick HA, Menzies D, Ondrusek M, Wan Z, Waters KJ (1992) Ozone depletion: ultraviolet radiation and phytoplankton biology in Antarctic waters. Science 255:952-959

Solorzano L (1969) Determination of ammonia in natural waters by the phenolhypochlorite method. Limnol Oceanogr 14:799-801

Stoecker DK, Egloff DA (1987) Predation by Acartia tonsa Dana on planktonic ciliates and rotifers. J Exp Mar Biol Ecol 110:53-68

Stramski D, Reynolds RA (1993) Diel variations in the optical

Editorial responsibility: Fereidoun Rassoulzadegan

(Contributing Editor), Villefranche-sur-Mer, France properties of a marine diatom. Limnol Oceanogr 38 $1347-1364$

Tarasick DW, Fioletov VE (1997) The distribution of ozone and ozone-depleting substances in the atmosphere and observed changes. In: Wardle DI, Kerr JB, McElroy CT, Francis DR (eds) Ozone science: a Canadian perspective on the changing ozone layer. Enviromment Canada. University of Toronto Press, Toronto, p 9-14

Taylor FJR (1980) Basic biological features of phytoplankton cells. In: Morris I (ed) The physiological ecology of phytoplankton. Blackwell, Oxford, p 3-55

Van Donk E, Hessen DO (1995) Reduced digestibility of UV-B stressed and nutrient-limited algae by Daphnia magna. Hydrobiologia 307:147-151

Vincent WF, Roy $S$ (1993) Solar ultraviolet-B radiation and aquatic primary production: damage, protection, and recovery. Environ Rev 1:1-12

Wiadnyana NN, Rassoulzadegan F (1989) Selective feeding of Acartia clausi and Centropages typicus on microzooplankton. Mar Ecol Prog Ser 53:37-45

Submitted: January 4, 1999; Accepted: May 31, 1999 Proofs received from author(s): September 17, 1999 